\title{
Pembangunan Perangkat Pendeteksi Jenis Gerakan Raket Bulu Tangkis Dengan Algoritma KNN dan SVM
}

\author{
Raymond Chandra Putra \\ Program Studi Teknik Informatika, Universitas Katolik Parahyangan, Bandung, Jawa Barat \\ Email: raymond.chandra@unpar.ac.id
}

(Naskah masuk: 23 Sep 2020, direvisi: 19 Okt 2020, diterima: 23 Okt 2020)

\begin{abstract}
Abstrak
Internet of Things (IoT) dapat diaplikasikan untuk banyak bidang, salah satunya pada latihan olahraga bulu tangkis. Pada olahraga bulu tangkis, terutama bagi pemain pemula mengalami kesulitan untuk mengetahui apakah gerakan yang dilakukan sudah benar atau belum. Pada penelitian ini, dibangun sebuah embedded system yang dipasang pada raket yang berfungsi mengambil data gerakan pukulan. Data pukulan ini dikirim ke sebuah perangkat lunak yang dapat mendeteksi jenis gerakan raket bulu tangkis. Embedded system terdiri dari Arduino dan sensor accelerometer dan gyroscope. Data pukulan disimpan ke dalam basis data melalui web service. Perangkat lunak dibangun dengan memanfaatkan prinsip pembelajaran mesin terarah yaitu klasifikasi. Algoritma klasifikasi yang digunakan adalah algoritma $k$-Nearest Neighbor dan membandingkan hasilnya dengan algoritma lain yaitu Support Vector Machine. Pengujian dilakukan dengan mengumpulkan data latih yang digunakan oleh algoritma klasifikasi untuk memprediksi gerakan. Kinerja dari kedua algoritma klasifikasi diukur dan dibandingkan. Dari hasil pengujian, maka disimpulkan bahwa algoritma Support Vector Machine menghasilkan kinerja yang lebih baik dari $k$-Nearest Neighbor dalam mendeteksi gerakan raket. Selain itu kinerja algoritma Support Vector Machine yang lebih baik tersebut dihasilkan dengan data latih yang lebih sedikit dibandingkan $k$-Nearest Neighbor.
\end{abstract}

Kata Kunci: Bulu Tangkis, Accelerometer, Gyroscope, Klasifikasi, k-Nearest Neighbor, Support Vector Machine.

\section{Development of Badminton Racket Motion Detector Using KNN and SVM Algorithm}

\begin{abstract}
Internet of Things (IoT) is used in many different fields including badminton. In badminton, beginner players often encounter difficulties during training because they are unable to monitor their own movements. In this research, we developed the embedded system to capture the motion data from the badminton racket. Captured data is sent to the database via web service. The software is developed using classification technique which is one of the supervised machine learning principles. The classification algorithms used in this research are k-Nearest Neighbor and Support Vector Machine. The prediction results from the two algorithms are then compared. Testing is carried out by collecting training data and then processed through classification algorithms to determine the class. Each class represents different types of racket motions. From the test results, we concluded that the Support Vector Machine algorithm performs better than k-Nearest Neighbor in predicting type of racket motion. The classification using Support Vector Machine algorithm will produce better results even with fewer training data.
\end{abstract}

Keywords: Badminton, Accelerometer, Gyroscope, k-Nearest Neighbor, Support Vector Machine.

\section{PENDAHULUAN}

Dengan kesibukan di zaman modern ini, makin banyak orang yang enggan berolahraga, terlebih lagi beberapa olahraga membutuhkan kemampuan khusus, contohnya pada olahraga bulu tangkis. Diperlukan waktu yang cukup lama untuk dapat meningkatkan kemampuan bermain bulu tangkis. 
Kemampuan tersebut dapat meningkat dengan pengamatan dari pihak yang lebih ahli seperti pelatih yang terkadang cukup mahal. Selain pengamatan dari pelatih, dapat pula dilakukan pengamatan dengan mengambil rekaman video latihan untuk ditonton kembali. Hal ini juga dianggap tidak terlalu akurat akibat faktor jarak dan sudut pengambilan rekaman. Dari permasalahan ini, dibutuhkan suatu perangkat yang dapat mempermudah mendeteksi gerakan raket bulu tangkis tanpa membutuhkan biaya yang mahal.

Untuk menjawab permasalahan tersebut, pada penelitian ini dibangun sebuah embedded system berbasis Internet of Things (IoT) yang mampu menangkap pergerakan raket yang kemudian mampu mendeteksi gerakan apa yang dilakukan. Untuk membangun perangkat ini diperlukan satu buah pengendali mikro yaitu Arduino dan dua buah sensor gerak yaitu accelerometer dan gyroscope. Accelerometer berfungsi untuk menangkap percepatan benda ketika benda tersebut digerakkan. Sedangkan gyroscope berfungsi untuk mendapatkan kemiringan dari suatu benda ketika benda tersebut digerakkan. Kedua sensor ini dikombinasikan untuk mendapatkan hasil terbaik.

Untuk mendeteksi pergerakan tersebut, data gerak yang sebelumnya dikumpulkan oleh sensor dikirim melalui web services dan disimpan pada basis data. Setelah data tersebut tersimpan, maka data tersebut digunakan untuk menentukan jenis gerakan dengan menggunakan metode pembelajaran mesin (machine learning). Pembelajaran mesin merupakan bidang ilmu yang memungkinkan suatu program komputer untuk melakukan tugas tertentu tanpa diberikan instruksi secara eksplisit. Hal ini menyebabkan pembuat sistem tidak perlu menuliskan instruksi atau aturan tersebut secara manual.

Dengan pembelajaran mesin, sistem akan melakukan aksi tertentu berdasarkan dengan data yang sudah dilatih ke sistem tersebut yang disebut dengan data training. Ada beberapa pendekatan dalam melakukan pelatihan data yaitu pembelajaran terarah (supervised learning), pembelajaran tidak terarah (unsupervised learning), dan pembelajaran semi terarah (semi-supervised learning). Di antara ketiga pendekatan tersebut pada penelitian ini digunakan pendekatan terarah.

Pada olahraga bulu tangkis, ada beberapa gerakan yang dapat dilakukan, diantaranya forehand, backhand, dan smash. Untuk menentukan apakah suatu gerakan masuk ke kategori tertentu, dilakukan klasifikasi data. Klasifikasi adalah suatu metode pengelompokan untuk data yang mempunyai label atau target. Dengan klasifikasi, kita mengajari mesin cara membagi data pukulan berdasarkan label tersebut dan menggunakan data hasil klasifikasi ini untuk mendeteksi jenis pukulan. Algoritma klasifikasi yang digunakan dalam penelitian ini adalah $k$-Nearest Neighbor dan Support Vector Machine. Kedua algoritma ini akan dibandingkan pada segi hasil deteksi dan kinerjanya dalam mengklasifikasi data gerakan pukulan.

Dengan penelitian ini, diharapkan hasil embedded system yang dibangun dapat membantu orang-orang yang ingin berolahraga dan belajar pukulan bulu tangkis dengan waktu yang lebih singkat dan biaya rendah.
Beberapa karya terkait yang mendasari penelitian ini adalah sebagai berikut:

- A. I. Anik, dkk. [1] melakukan penelitian sejenis untuk mendeteksi gerakan badminton dengan sensor akselerometer.

- M. I. Rusydi, dkk. [2] melakukan penelitian untuk mencari pola gerakan smash dan backhand pada olahraga bulu tangkis berdasarkan posisi tangan.

- N. Ravi, dkk. [3] melakukan penelitian untuk mendeteksi gerakan aktivitas manusia secara umum dengan data akselerometer.

- L. B. Pardo, dkk. [4] melakukan penelitian sejenis untuk mendeteksi gerakan pada olahraga tenis yang secara umum memiliki banyak persamaan dengan bulu tangkis.

- T. Kamiyama, dkk. [5] melakukan penelitian untuk mendeteksi perpindahan pemain bulu tangkis dengan menggunakan kamera.

- N. A. Rahmad, dkk. [6] melakukan penelitian mendeteksi gerakan pemain bulu tangkis dengan algoritma FR-CNN.

\section{LANDASAN TEORI}

A. Bulu Tangkis

Bulu tangkis merupakan olahraga yang dimainkan oleh dua tim yang terdiri dari 1 orang untuk tunggal dan 2 orang untuk ganda dan saling berlawanan menggunakan raket dan kok [7]. Pada bulu tangkis terdapat beberapa pukulan yaitu:

- Servis: pukulan ketika memulai permainan yang dapat dilakukan dengan servis pendek maupun panjang.

- Lob: pukulan yang diarahkan ke belakang lapangan.

- Drive: pukulan yang diarahkan mendatar dapat dilakukan secara forehand maupun backhand.

- Smash: pukulan yang dipukul secara tajam dan menukik dari atas ke bawah.

- Dropshot: pukulan yang diarahkan dekat dengan net.

\section{B. Pengendali Mikro}

Pengendali mikro merupakan sebuah chip yang berfungsi sebagai pengontrol rangkaian elektronik. Pada sebuah pengendali mikro terdapat CPU, memori, input, dan output [8]. Salah satu contoh pengendali mikro yang terkenal adalah Arduino. Untuk mendeteksi pergerakan, pengendali mikro dilengkapi dengan sensor gerak yaitu accelerometer dan gyroscope dengan penjelasan sebagai berikut:

- Accelerometer [8]

Accelerometer adalah sebuah alat atau transduser untuk mengukur kekuatan percepatan sehingga dapat mendeteksi adanya perubahan posisi perangkat dan mengukur berapa besar perubahan yang terjadi. Accelerometer memiliki tiga sumbu x, y, dan $\mathrm{z}$ yang dapat dilihat pada Gambar 1. Jika benda bergerak ke arah sumbu positif, maka hasil pengukuran akan semakin besar, dan sebaliknya jika benda bergerak ke arah negatif maka hasil pengukuran akan berkurang. 


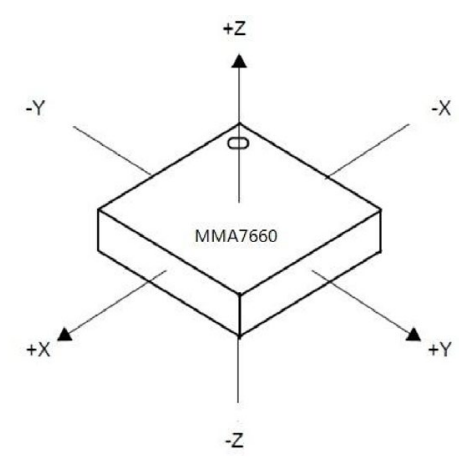

Gambar 1. Sumbu Pada Sensor Accelerometer

- Gyroscope [9]

Gyroscope adalah suatu alat navigasi yang dapat digunakan untuk mengukur orientasi perangkat. Cara kerja gyroscope adalah dengan mengukur kecepatan sudut dan seberapa cepat mengelilingi suatu sumbu. Gyroscope mempunyai 3 sumbu $\mathrm{x}, \mathrm{y}$, dan $\mathrm{z}$ yang dapat dilihat pada Gambar 2. Jika suatu benda berputar sesuai arah sumbu positif, maka nilai pengukuran akan semakin besar, sebaliknya jika benda berputar melawan arah sumbu positif, maka nilai pengukuran akan semakin berkurang.

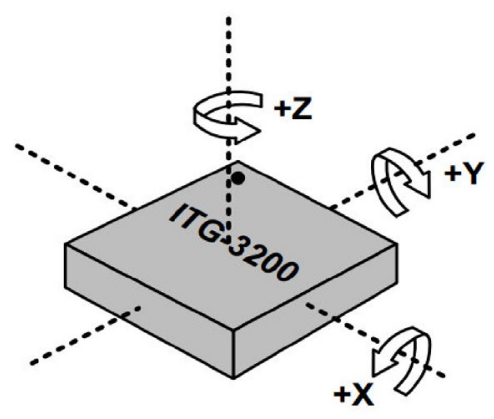

Gambar 2. Sumbu Pada Sensor Gyroscope.

\section{Pembelajaran Mesin [10]}

Pembelajaran mesin merupakan bidang ilmu yang memungkinkan suatu program komputer untuk melakukan tugas tertentu tanpa diberikan instruksi secara eksplisit. Pembelajaran mesin digerakan oleh agen. Agen merupakan sistem yang dapat mempersepsikan lingkungan melalui sensor dan bereaksi terhadap lingkungan melalui aktuator. Dalam perancangan pembelajaran mesin, terdapat beberapa jenis pembelajaran yaitu sebagai berikut [11]:

- Pembelajaran Terarah (Supervised Learning)

Pembelajaran Terarah adalah jenis pembelajaran mesin dimana agen perlu melakukan observasi terhadap beberapa data untuk dapat memetakan masukan dengan keluaran. Contoh algoritma yang termasuk pembelajaran terarah adalah Decision Tree, Naïve Bayes, $k$-Nearest Neighbor, dan Support Vector Machine.

- Pembelajaran Tidak Terarah (Unsupervised Learning) Pembelajaran Tidak Terarah adalah jenis pembelajaran dimana agen perlu mempelajari ciri-ciri yang terdapat dari sebuah data. Ketika agen diperkenalkan data baru, maka agen akan menggunakan ciri yang dipelajari sebelumnya untuk mengenali data tersebut. Contoh algoritma pembelajaran tidak terarah adalah $K$-means Clustering dan Principal Component Analysis.

- Pembelajaran Semi Terarah (Semi-supervised Learning) Pembelajaran Semi-terarah adalah pengembangan dari kedua pembelajaran sehingga agen akan mendapatkan sedikit masukan dan keluaran. Akan tetapi, pada pembelajaran ini dilakukan pula pengenalan ciri dari data tersebut. Contoh algoritma pembelajaran semi terarah adalah Generative Models, Self-Training, dan Transductive.

\section{K-Nearest Neighbor (KNN) [12]}

Algoritma KNN adalah algoritma klasifikasi yang melakukan prediksi terhadap suatu objek berdasarkan data pembelajaran yang jaraknya paling dekat dengan objek tersebut. Algoritma KNN termasuk ke dalam algoritma pembelajaran terarah. Pada algoritma KNN data akan dibagi menjadi data latih dan juga data tes. Data latih akan diproyeksikan ke ruang berdimensi banyak, dimana masingmasing dari dimensi merepresentasikan fitur dari data. Ruang ini dibagi menjadi bagian-bagian berdasarkan klasifikasi data latih.

Data tes akan diubah menjadi sebuah titik yang berada dalam sebuah ruang dimensi banyak. Sebuah titik akan dimasukan ke dalam sebuah kelas tertentu berdasarkan data latih yang sudah diproyeksikan ke dalam ruang berdimensi banyak. Titik tersebut akan dibandingkan dengan semua titik yang ada di dalam data latih dan dicari $\mathrm{k}$ buah titik yang paling mirip dengan titik tersebut. Dari k buah yang paling mirip tersebut dicari kelas dari titik-titik yang paling mirip dengan titik tersebut. Kelas itu yang akan menjadi kelas bagi data tes.

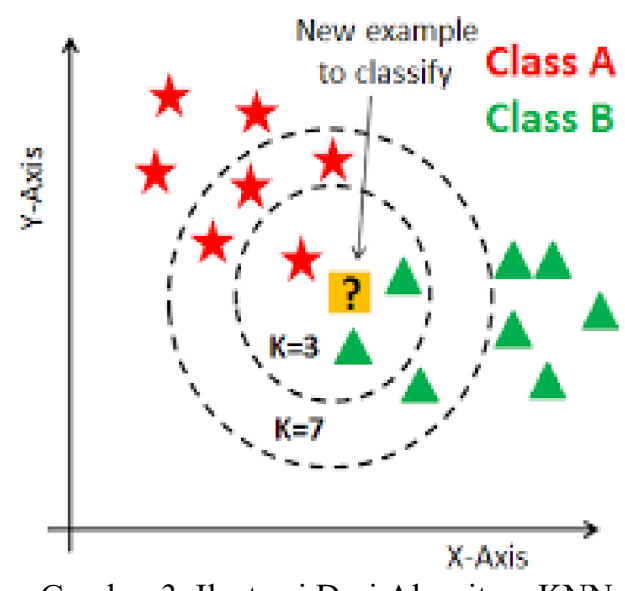

Gambar 3. Ilustrasi Dari Algoritma KNN.

Ilustrasi dari KNN dapat dilihat pada Gambar 3. Pada gambar tersebut diperlihatkan berapa $\mathrm{k}$ buah data dengan kemiripan terdekat dari data yang ditandai symbol "?”.

\section{E. Support Vector Machine (SVM) [13]}

Algoritma SVM adalah salah satu algoritma pembelajaran mesin terarah yang digunakan untuk melakukan prediksi dengan metode klasifikasi. SVM memiliki prinsip dasar linear 
classifier yang mampu memisahkan kasus klasifikasi secara linear dapat dipisahkan. SVM bekerja dengan cara mendefinisikan batas antara kelas-kelas yang disebut dengan hyperplane (garis pemisah). Tingkat optimal dari hyperplane ditentukan dari seberapa jauh margin hyperplane dengan titik terdekat dari masing-masing kelas. Ilustrasi SVM dapat dilihat pada Gambar 4.

Tidak semua data dapat dipisahkan secara linear, oleh karena itu SVM dikembangkan dengan menggunakan fungsi kernel. Dengan menambahkan fungsi kernel pada SVM, maka data akan dipetakan ke ruang vektor yang lebih tinggi sehingga hyperplane dapat dikonstruksikan. Beberapa jenis kernel yang biasa digunakan adalah Kernel Linear, Kernel Polynomial, Kernel RBF.

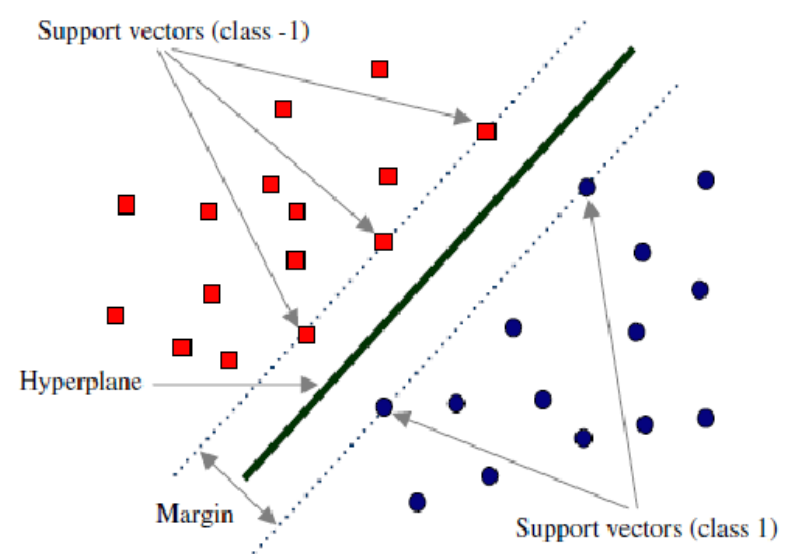

Gambar 4. Ilustrasi Hyperplane Pada SVM.

\section{METODE PENELITIAN}

\section{A. Alur Kerja Sistem}

Untuk dapat mengidentifikasi pergerakan dari setiap pukulan, maka pada penelitian ini digunakan sensor gerak accelerometer dan gyroscope yang dioperasikan dengan menggunakan pengendali mikro Arduino. Setiap pukulan akan menghasilkan nilai sensor yang berbeda. Nilai pengukuran ini akan disimpan di dalam basis data. Untuk mencapai basis data, data dari sensor harus dikirimkan ke server dengan menggunakan jaringan komputer. Data pukulan dikirimkan melalui web service menggunakan protokol HTTP GET.

Mendeteksi gerakan pukulan raket bulu tangkis merupakan salah satu pengenalan aktivitas manusia. Aktivitas manusia merupakan kegiatan yang kompleks sehingga cukup sulit jika setiap langkah instruksi dituliskan secara manual. Proses deteksi dapat memanfaatkan konsep pembelajaran mesin yang sudah banyak digunakan untuk mengenal aktivitas manusia. Pembelajaran mesin untuk mengenali jenis pukulan ini dapat menggunakan prinsip pembelajaran terarah dengan metode klasifikasi. Algoritma klasifikasi yang digunakan adalah k-nearest Neighbor dan Support Vector Machine. Proses pendeteksi gerakan raket ini secara sederhana dapat dilihat pada Gambar 5.

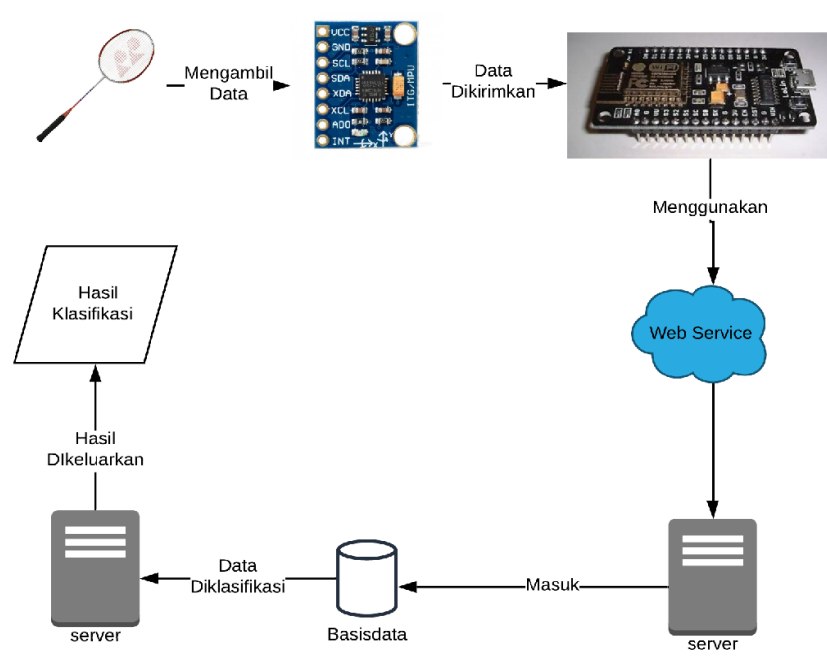

Gambar 5. Diagram Proses Pendeteksi Gerakan Raket.

B. Analisis Pengambilan Data

Untuk mendeteksi pergerakan, digunakan sensor gerak accelerometer dan gyroscope. Pada penelitian ini, digunakan sensor jenis MPU-6050 yang terdiri dari 3 buah sensor, yaitu accelerometer, gyroscope, dan termometer. Hasil penangkapan termometer akan diabaikan. Sensor ini dapat menangkap nilai accelerometer dan gyroscope pada sumbu X, $\mathrm{Y}$, dan Z dalam waktu bersamaan. Sensor MPU-6050 ini menggunakan 12C-bus yang dapat dikoneksikan dengan Arduino. Sensor ini ditempatkan pada area senar raket bulu tangkis. Karena ukuran sensor yang begitu kecil dan rapuh, maka sensor ini dilindungi casing penutup dengan menggunakan roset telepon. Untuk menghubungkan sensor dengan Arduino, digunakan kabel RJ11 atau kabel telepon.

Setelah sensor menangkap data dari pukulan, maka data tersebut dikirimkan ke dalam basis data. Data tersebut dikirimkan dengan menggunakan jaringan nirkabel ( $\mathrm{WiFi}$ ). Pada penelitian ini digunakan Arduino Lolin NodeMCU ESP8266 yang sudah memiliki WiFi di dalamnya. Dengan menggunakan Arduino, pengambilan data dapat dilakukan dimanapun selama Arduino dan server basis data berada di jaringan yang sama. Data yang dikirimkan ke server adalah sebagai berikut:

- Id: Id dari data pukulan yang diambil sensor

- Ax: Nilai data accelerometer pada sumbu X

- Ay: Nilai data accelerometer pada sumbu Y

- Az: Nilai data accelerometer pada sumbu Z

- Gx: Nilai data gyroscope pada sumbu X

- Gy: Nilai data gyroscope pada sumbu Y

- Gz: Nilai data gyroscope pada sumbu Z

- counter: Urutan pemukulan data pada suatu pukulan

- hit: Nomor urut pukulan

- time: Waktu pengambilan pukulan

Seluruh data tersebut disimpan pada 4 tabel basis data yang terdiri dari 3 tabel data latih untuk 3 jenis gerakan dan 1 tabel untuk proses pendeteksi gerakan. 


\section{Analisis Pemilihan Fitur}

Data yang tersimpan pada basis data merupakan data mentah hasil penangkapan sensor langsung dengan 3 buah sumbu. Data mentah ini tidak dapat digunakan secara langsung dikarenakan sulitnya melakukan analisis data dari data mentah tersebut. Contoh data mentah yang disimpan dapat dilihat pada Tabel 1. Setiap baris menunjukkan satu kali pengambilan sensor pada interval tertentu. Pada penelitian ini interval yang digunakan adalah $50 \mathrm{~ms}$.

Tabel 1. Contoh Data Mentah Gerakan Raket

\begin{tabular}{llllll}
\hline $\mathbf{A x}$ & $\mathbf{A y}$ & $\mathbf{A z}$ & $\mathbf{G x}$ & $\mathbf{G y}$ & $\mathbf{G z}$ \\
\hline$-0,36$ & 0,82 & $-0,68$ & $-13,68$ & $-3,94$ & $-3,6$ \\
\hline$-0,37$ & 0,82 & $-0,64$ & $-13,68$ & $-9,65$ & 11,05 \\
\hline$-0,16$ & 0,72 & $-0,61$ & $-13,56$ & 2,06 & 15,22 \\
\hline$-0,11$ & 0,85 & $-0,48$ & $-13,44$ & $-21,03$ & $-6,74$ \\
\hline 0,19 & 1,04 & $-0,41$ & $-13,56$ & $-43,13$ & $-11,15$ \\
\hline
\end{tabular}

Oleh karena itu, dibutuhkan proses pengolahan data mentah untuk kebutuhan klasifikasi data. Untuk mengklasifikasikan data, dibutuhkan fitur-fitur tertentu sebagai dasar penentuan kelas. Pada kasus pendeteksi aktivitas manusia digunakan fitur-fitur pada Tabel 2. [1]

Tabel 2. Fitur-Fitur Dari Data Gerakan

\begin{tabular}{ll}
\multicolumn{1}{c}{ Fitur } & \multicolumn{1}{c}{ Deskripsi } \\
\hline Rata-rata & $\begin{array}{l}\text { Nilai rata-rata dari accelerometer } \text { dan } \\
\text { gyroscope pada ketiga sumbu. }\end{array}$ \\
\hline Median & $\begin{array}{l}\text { Nilai tengah dari accelerometer } \text { dan } \\
\text { gyroscope pada ketiga sumbu. }\end{array}$ \\
\hline Nilai & $\begin{array}{l}\text { Nilai puncak positif dari accelerometer } \\
\text { dan gyroscope pada ketiga sumbu. }\end{array}$ \\
\hline Nertinggi & $\begin{array}{l}\text { Nilai puncak negatif dari } \text { accelerometer } \\
\text { Terendah } \text { gyroscope pada ketiga sumbu. }\end{array}$ \\
\hline Energi & $\begin{array}{l}\text { Nilai absolut dari FFT (Fast Fourier } \\
\text { Transform) dari accelerometer } \text { dan } \\
\text { gyroscope } \text { pada ketiga sumbu. }\end{array}$ \\
&
\end{tabular}

Data mentah dari sensor accelerometer dan gyroscope berjumlah 6 data (masing-masing sensor memiliki 3 sumbu). Setiap data tersebut dinormalisasi dengan menggunakan fitur pada Tabel 2. Nilai dari fitur-fitur tersebut akan disatukan dan dijadikan sebuah vektor pukulan. Jadi akan terdapat 30 nilai yang akan digabungkan pada sebuah vektor.

\section{Mendeteksi Gerakan}

Setelah dilakukan proses pengolahan data, maka akan didapatkan sebuah vektor dengan 30 nilai fitur untuk setiap gerakan. Vektor ini adalah masukan yang digunakan dalam proses klasifikasi dengan algoritma KNN dan SVM. Pada kedua algoritma akan terdapat kumpulan vektor data latih yang sudah diberi label kelas tertentu dan vektor yang digunakan untuk data tes. Setiap kelas merepresentasikan satu jenis gerakan raket.

Pada algoritma KNN, akan dihitung nilai kemiripan antara vektor data tes dengan semua vektor data latih dengan menggunakan persamaan Euclidean distance. Kemudian hasil kemiripan tersebut diurutkan dan diambil $\mathrm{k}$ buah data yang paling mirip. Pada penelitian ini digunakan nilai $\mathrm{k}=7$. Hasil prediksi gerakan merupakan kelas terbanyak diantara $\mathrm{k}$ buah data tersebut.

Pada algoritma SVM, vektor data latih akan diproyeksikan ke dalam ruang berdimensi banyak yang masing-masing dimensi tersebut merepresentasikan fitur dari data. Pada SVM, akan dicari hyperplane yang memisahkan seluruh data latih menjadi banyak kelas. Pada penelitian ini digunakan kernel linear yang menyebabkan hyperplane yang dihasilkan menjadi linear. Vektor data tes yang ingin diprediksi, diproyeksikan ke ruang berdimensi banyak yang telah dibuat sebelumnya. Titik data tes tersebut diletakkan menentukan kelas dari gerakan tersebut dan secara langsung menjadi hasil dari prediksi gerakan.

\section{E. Perancangan}

Untuk membangun sistem ini, dilakukan beberapa perancangan yang diantaranya adalah perancangan alat, perancangan use case, dan diagram aktivitas.

Perancangan alat dilakukan terhadap perangkat keras yang dibutuhkan untuk membangun embedded system. Perancangan alat ini dapat dilihat pada Gambar 6.

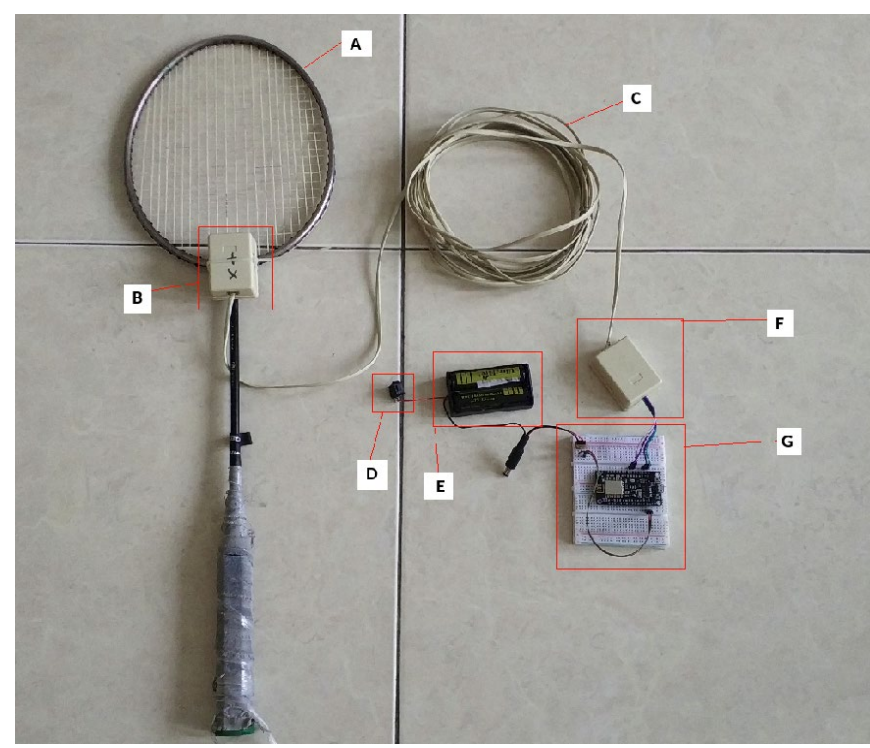

Gambar 6. Perancangan Alat Pendeteksi Gerak.

Keterangan dari gambar tersebut adalah sebagai berikut:

A. Raket bulu tangkis.

B. Roset telepon yang terdapat sensor accelerometer dan gyroscope.

C. Kabel telepon (RJ11) sebagai penghubung sensor dengan Arduino.

D. Mini power switch

E. Baterai 3.7 volt 
F. Roset telepon yang menghubungkan sensor dengan Arduino.

G. Arduino Lolin NodeMCU ESP8266.

Skema rangkaian alat elektronik secara detail dapat dilihat pada Gambar 7. Arduino dihubungkan dengan sensor yang memiliki accelerometer dan gyroscope. Lalu agar alat ini dapat dibawa kemana-mana maka digunakan sumber listrik baterai 3.7 volt.

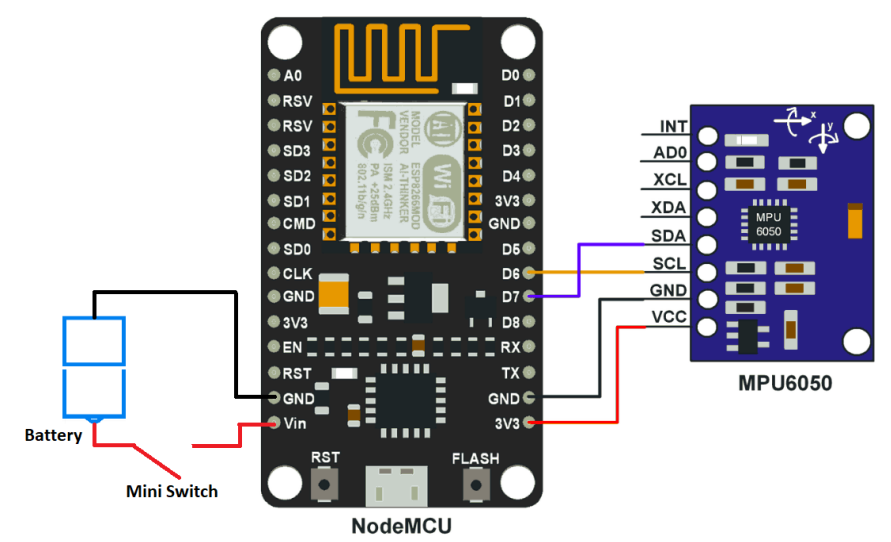

Gambar 7. Skema Rangkaian Alat Elektronik.

Interaksi antara perangkat lunak dengan pengguna dapat digambarkan melalui diagram use case yang dapat dilihat pada Gambar 8 .

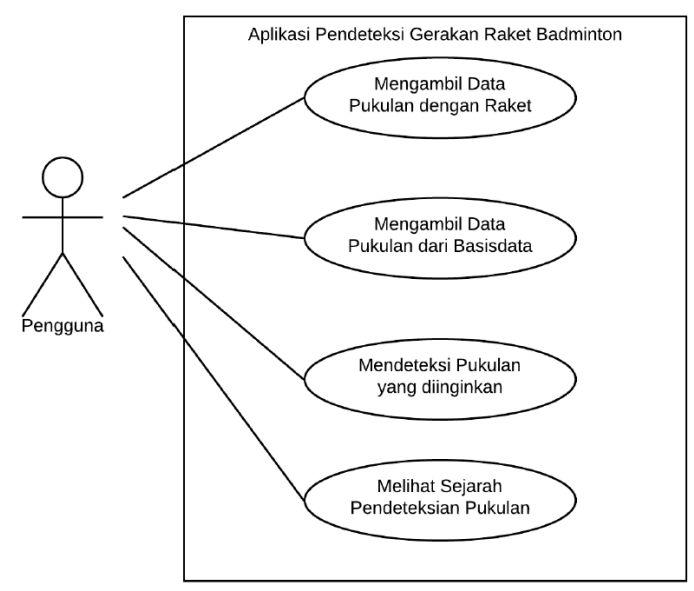

Gambar 8. Diagram Use Case Aplikasi Pendeteksi Gerakan Raket Badminton

Pada Gambar 8 diperlihatkan bahwa pengguna dapat mengambil data pukulan dengan raket yang otomatis langsung tersimpan ke basis data, mengambil data pukulan dari basis data, mendeteksi pukulan dari data yang sudah tersimpan di basis data, dan pengguna dapat melihat sejarah pendeteksi pukulan.

Alur kerja dari sistem yang dibangun dapat digambarkan melalui diagram aktivitas pada Gambar 9. Ketika aplikasi dimulai, maka pengguna dapat menggerakkan raket sesuai dengan jenis pukulan yang mau dideteksi oleh sistem ini.
Selanjutnya sensor akan menangkap data ini dan mengirimkan data ke server melalui web service.

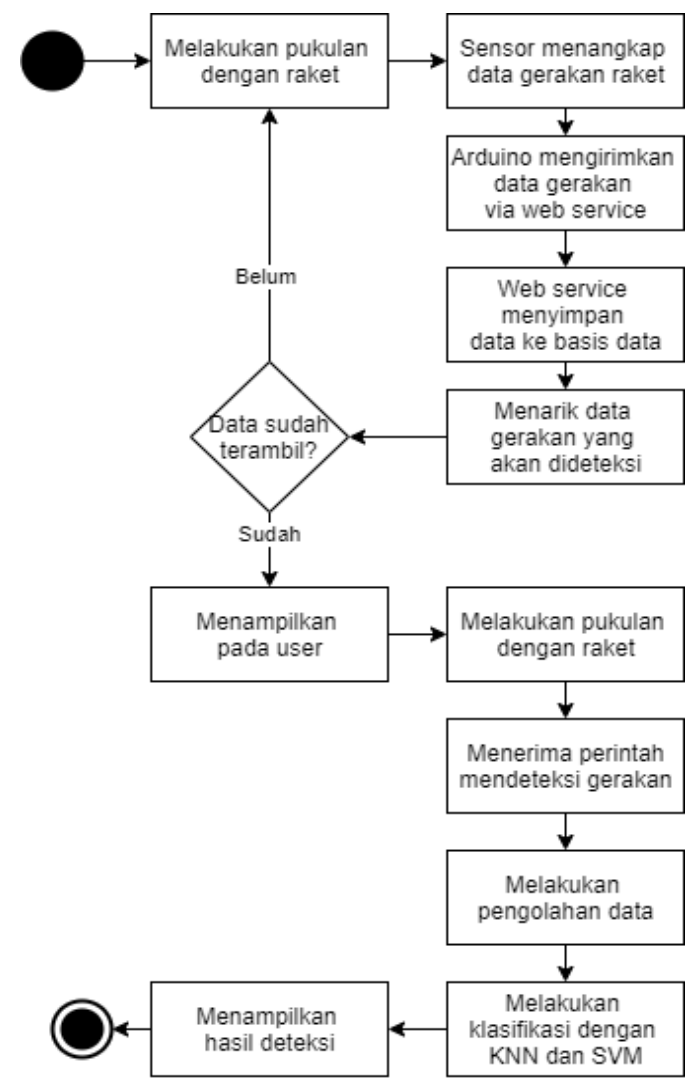

Gambar 9. Diagram Aktivitas Perangkat Lunak Pendeteksi Gerakan Raket

Web Service ini bertugas menyimpan data yang dikirimkan ke dalam basis data. Jika data tidak berhasil tersimpan, maka pengguna dapat mengulangi pengambilan data. Jika data gerakan sudah tersimpan, pengguna dapat menekan perintah untuk melakukan deteksi pukulan.

Dengan melakukan perintah untuk mendeteksi, perangkat lunak akan melakukan pengolahan data dan melakukan klasifikasi berdasarkan fiturnya. Hasil pendeteksi akan ditampilkan di layar pengguna.

\section{HASIL DAN PEMBAHASAN}

Penelitian ini menghasilkan sistem yang terdiri dari 3 perangkat yaitu:

1. Sebuah embedded system dengan meletakkan Arduino di raket untuk mengambil data berdasarkan sensor gerak yang terpasang,

2. Sebuah web service yang diakses oleh Arduino untuk mengirimkan data-data yang tertangkap dan memasukkan data ke dalam basis data.

3. Sebuah perangkat lunak dalam bahasa Python yang berfungsi mengambil data dari basis data, melakukan pengolahan data, dan melakukan klasifikasi dari data latih. Selain itu, perangkat lunak ini juga digunakan untuk melakukan pendeteksi gerakan berdasarkan klasifikasi 
tersebut. Pada Gambar 10 dapat dilihat antarmuka yang menunjukkan hasil pendeteksiaan dari klasifikasi ini.

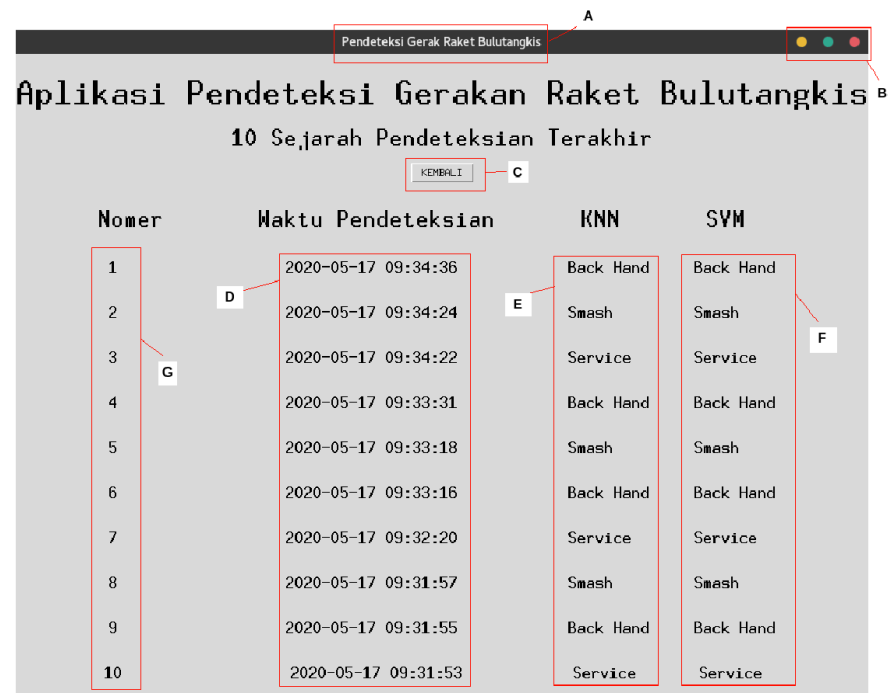

Gambar 10. Hasil Pendeteksi Gerakan pada Antarmuka Perangkat Lunak

Pengujian dilakukan terhadap sistem yang sudah dibuat untuk mendeteksi 3 jenis gerakan yaitu backhand, servis, dan smash. Untuk setiap jenis pukulan, digunakan 2 jenis data latih yang berjumlah 30 data dan 75 data. Dari kedua jenis data latih tersebut dilakukan klasifikasi dengan 2 algoritma berbeda yaitu KNN dan SVM.

Pengujian dilakukan dengan menghitung waktu eksekusi perangkat lunak dari waktu pengguna memberikan perintah pendeteksi sampai pukulan berhasil dideteksi. Waktu eksekusi ini tidak termasuk waktu pengambilan data dan pemilihan pukulan. Untuk mengetahui waktu eksekusi, dilakukan 20 kali percobaan dan diambil rata-rata dari waktu eksekusi tersebut. Hasil pengujian untuk mengetahui waktu eksekusi dapat dilihat pada Tabel 3. Waktu eksekusi dihitung dalam satuan milidetik.

Tabel 3. Hasil Pengujian (Waktu eksekusi)

\begin{tabular}{lccr}
\hline \multirow{2}{*}{$\begin{array}{c}\text { Jenis } \\
\text { Gerakan }\end{array}$} & $\begin{array}{c}\text { Data } \\
\text { Latih }\end{array}$ & KNN & SVM \\
\hline \multirow{2}{*}{ Service } & 30 & 25 & 29 \\
\cline { 2 - 4 } & 75 & 52 & 46 \\
\hline \multirow{2}{*}{ Smash } & 30 & 29 & 27 \\
\hline \multirow{2}{*}{ Backhand } & 75 & 46 & 41 \\
\cline { 2 - 4 } & 30 & 35 & 23 \\
\hline
\end{tabular}

Selain itu, pengujian juga dilakukan untuk mengukur ketepatan klasifikasi dari kedua algoritma. Jadi akan dicatat berapa banyak pukulan yang berhasil dideteksi dengan benar dan berapa yang salah. Percobaan dilakukan sebanyak 20 kali dan dihitung berapa persentase pendeteksi yang benar dibandingkan seluruh percobaan. Hasil pengujian untuk mengetahui akurasi dari pendeteksi dapat dilihat pada Tabel 4.
Tabel 4. Hasil Pengujian (Akurasi)

\begin{tabular}{cccc}
\hline \multirow{2}{*}{$\begin{array}{c}\text { Jenis } \\
\text { Gerakan }\end{array}$} & $\begin{array}{c}\text { Data } \\
\text { Latih }\end{array}$ & KNN & SVM \\
\hline \multirow{2}{*}{ Service } & 30 & $95 \%$ & $95 \%$ \\
\cline { 2 - 4 } & 75 & $95 \%$ & $95 \%$ \\
\hline \multirow{2}{*}{ Smash } & 30 & $65 \%$ & $85 \%$ \\
\hline \multirow{2}{*}{ Backhand } & 75 & $85 \%$ & $85 \%$ \\
\cline { 2 - 4 } & 30 & $65 \%$ & $85 \%$ \\
\hline
\end{tabular}

Dari hasil pengujian yang sudah dipaparkan, ada beberapa hal yang dapat dilakukan analisis yaitu:

1. Banyaknya data latih

Dari hasil pengujian, banyaknya data latih mempengaruhi waktu eksekusi walaupun tidak signifikan. Semakin banyak data, maka waktu eksekusi akan semakin lama. Selain itu banyak data latih juga mempengaruhi akurasi keberhasilan pendeteksi gerakan. Semakin banyak data latih maka semakin tinggi juga akurasi keberhasilan pendeteksi.

2. Perbandingan algoritme KNN dan SVM.

Pengujian dilakukan dengan menggunakan dua algoritma yang berbeda yaitu KNN dan SVM. Dari data pengujian dapat diambil kesimpulan bahwa kinerja SVM relatif lebih baik dalam mendeteksi data pergerakan raket. Pada data latih yang sedikit, SVM menunjukkan tingkat akurasi cukup signifikan dibandingkan KNN. Walaupun dengan bertambahnya data latih, kinerja KNN menjadi lebih baik, waktu eksekusi yang dibutuhkan pun meningkat. Sedangkan SVM dapat mencapai akurasi yang lebih tinggi walaupun jumlah latih sedikit.

\section{KESIMPULAN}

Pada penelitian ini telah berhasil diimplementasikan perangkat yang dapat mendeteksi jenis gerakan raket bulu tangkis. Perangkat tersebut terdiri dari sebuah embedded system, web service, dan perangkat lunak untuk melakukan klasifikasi. Perangkat lunak telah berhasil menangkap data pergerakan raket menggunakan sensor accelerometer dan gyroscope. Kemudian data tersebut dikirimkan untuk dilakukan pengolahan data. Data yang sudah diolah digunakan untuk melakukan klasifikasi dengan menggunakan algoritma k-Nearest Neighbor dan Support Vector Machine. Kedua algoritma mampu memprediksi jenis gerakan raket berdasarkan klasifikasi yang sudah dibuat.

Dari pengujian yang dilakukan, didapatkan hasil pendeteksi gerakan raket dengan kedua algoritma tersebut. Hasil menunjukkan untuk mengklasifikasikan data gerakan bulu tangkis, algoritma Support Vector Machine menunjukkan tingkat pendeteksi yang lebih baik dibandingkan algoritma $k$ Nearest Neighbor. Selain itu algoritma Support Vector Machine juga melakukan pendeteksi yang lebih cepat dibanding $k$-Nearest Neighbor, walaupun perbedaannya tidaklah signifikan. 


\section{SARAN}

Walaupun perangkat ini sudah berhasil mendeteksi gerakan raket, pada penelitian ini masih terdapat kekurangan. Pada penelitian ini, data gerakan diambil satu persatu walaupun kenyataannya ketika raket ini digunakan untuk berlatih bulu tangkis, raket akan digunakan untuk beberapa gerakan berurutan. Hal ini dapat diatasi dengan teknik dynamic time warping.

Selain itu untuk meningkatkan tingkat akurasi dari prediksi, dibutuhkan data latih lebih banyak dari berbagai jenis pengguna, misalnya dari pemain pemula maupun atlet bulu tangkis. Dengan bertambahnya data latih mungkin saja sistem dapat mendeteksi gerakan lain yang di penelitian ini belum mampu dilakukan. Kecepatan gerakan juga dapat menjadi komponen yang menarik untuk penelitian lebih lanjut.

\section{REFERENSI}

[1] Anik, A.I. \& Hassan, M. (2016). Activity Recognition of a Badminton Game Through Accelerometer and Gyroscope. Bangladesh: Islamic University of Technology Department of Computer Science and Engineering (CSE).

[2] Rusydi. (2015). Local Euler angle pattern recognition for smash and backhand in badminton based on arm position. Procedia Manufacturing, Vol. 3, pp. 898-903.

[3] Ravi, N., Dandekar, N., Mysore, P. \& Littman, M. (2005). Activity Recognition from Accelerometer Data. AAAI, Vol. 3, pp. 1541-1546.

[4] Pardo, L.B., Perez, D.B. \& Uruñuela, C.O. (2019). Detection of Tennis Activities withWearable Sensors. Sensors, Vol. 19.

[5] Kamiyama, T., Kameda, Y., Ohta, Y. \& Kitahara, I. (2017). Improvement of Badminton-Player Tracking Applying Image Pixel Compensation. ITE Transactions on Media Technology and Applications, Vol. 5(2), pp. 36-41.

[6] Rahmad, N.A., Sufri, N.A.J., Muzamil, N.H. \& As'ari, M.A. (2019). Badminton Player Detection Using Faster Region Convolutional Neural Network. Indonesian Journal of Electrical Engineering and Computer Science, Vol. 14, pp. 1330-1335.

[7] Hastuti, P. (2009). Buku Panduan Cabang Olahraga Bulutangkis Special Olympics 1st edition. Jakarta: Pengurus Pusat Special Olympics Indonesia.

[8] Permana, R.M. (2017). Pengembangan Media Pembelajaran Sensor dan Transduser Berbasis PC dengan Menggunakan Sensor-Sensor pada Smartphone Android. Yogyakarta: Lumbung Pustaka Universitas Negeri Yogyakarta.

[9] Immersa Lab. (2018). Pengertian Gyroscope dan Cara Kerjanya [Online]. Diakses dari: https://www.immersalab.com/pengertian-gyroscope-dan-cara-kerjanya.htm/ pada tanggal 15 September 2019.

[10] Dey, A. (2016). Machine Learning Algorithms: A Review. International Journal of Computer Science and Information Technologies (IJCSIT), Vol. 7(3), pp. 11741179.

[11] Ang, J., Mirzal, A., Haron, H. \& Hamed, H.N.A. (2015). Supervised, Unsupervised, and Semi-Supervised Feature Selection: a Review on Gene Selection. IEEE/ACM Transactions on Computational Biology and Bioinformatics, vol. 13.

[12] Delany, P.C., Jane, S. (2020). k-Nearest Neighbour Classifiers: 2nd Edition. arXiv.

[13] Pratama, A., Wihandika, R. \& Ratnawati, D.E. (2018). Implementasi Algoritma Support Vector Machine (SVM) untuk Prediksi Ketepatan Waktu Kelulusan Mahasiswa. Jurnal Pengembangan Teknologi Informasi dan Ilmu Komputer, Vol. 2, pp. 1704-1708. 